\title{
Efektivitas Komik Edukasi terhadap Upaya Pencegahan Kekerasan pada Anak Sekolah Dasar Negeri Penggilingan 09 Pagi Jakarta Timur Tahun 2019
}

\section{The Effectiveness of Educational Comics on The Prevention of Violence in Elementary School Children}

\author{
Triana Indrayani ${ }^{1}$, Nadya Namira ${ }^{2}$ \\ ${ }^{1}$ Study Program DIV Midwifery, National University, Jakarta \\ 2 Student Study Program DIV Midwifery, National University, Jakarta \\ Jalan RM. Harsono Blok Kenanga No. 11, Ragunan, Pasar Minggu, Jakarta 12550 \\ Email: triana.indrayani@yahoo.com
}

\section{KEYWORDS Educational Comics, Prevention of Violence, School Children}

ABSTRACT Comics are effective in increasing elementary school children's knowledge because comics have attractive colors and images, therefore they can facilitate easy understanding of a concept. One group of children who are vulnerable to being victims of sexual violence were elementary school children. This study aimed to measure the effectiveness of educational comics on the prevention of violence in elementary school children. The research design used in this study was a pre-experimental using the One Group Pre-Post-Test design, the sample in this study was 32 students taken using total sampling. The instrument used was a questionnaire, the data analysis used paired t test. The results showed that there were significant differences in the pretest and posttest after the educational comic intervention. There is a significant influence between the effectiveness of educational comics on prevention of violence in state elementary School Children before the intervention and after the intervention. It is expected that students will be more proactive in finding information about preventing violence in children so that they can apply the information obtained as well as possible.

\section{PENDAHULUAN}

Menurut United Nations International Children's Emergency Fund (UNICEF) saat ini, kekerasan terhadap anak terjadi secara luas di Indonesia, 40 persen anak berusia 13-15 tahun melaporkan pernah diserang secara fisik sedikitnya satu kali dalam setahun.
Sebanyak 26 persen melaporkan pernah mendapat hukuman fisik dari orang tua atau pengasuh di rumah. Sebanyak 50 persen anak melaporkan di-bully di sekolah, dan sekitar 45 persen perempuan dan anak perempuan di Indonesia percaya bahwa suami/pasangan boleh 
memukul istri/pasangannya dalam situasi-situasi tertentu (Maknun, 2017).

Menurut World Health Organization (WHO) 1 dari 4 orang dewasa melaporkan pernah mengalami kekerasan saat usia anak/remaja, 1 dari 5 Perempuan dan 1 dari 13 Laki-laki melaporkan pernah mengalami kekerasan seksual kekerasan saat usia anak/remaja, $12 \%$ anak-anak didunia mengalami kekerasan seksual pada satu tahun terakhir, $37 \%$ dari negara menerapkan intervensi pencegahan kejadian kekerasan seksual pada skala yang lebih besar (Adawiah, 2015).

Menurut World Health Organization (WHO) mendefinisikan kekerasan terhadap anak sebagai semua bentuk tindakan/perlakuan menyakitkan secara fisik ataupun emosional, penyalahgunaan seksual, penelantaran, eksploitasi, komersial atau lainnya yang mengakibatkan cedera/kerugian nyata ataupun potensial terhadap kesehatan anak, kelangsungan hidup anak, tumbuh kembang anak atau martabat anak, yang dilakukan dalam konteks hubungan tanggung jawab (Al Haq et al., 2017).

Komisi Nasional Pelanggaran

Anti-Perempuan (Komnas Perempuan) menyumbang pada tahun 2015321.752 kasus pelecehan perempuan, yang berarti bahwa sekitar 881 kasus terjadi setiap hari. Jumlahnya diperoleh dari pengadilan agama, 305.535 kasus, dan lembaga-lembaga di bawah kemitraan Komisi Nasional Pelanggaran Perempuan, 16.217 kasus hasil pengamatan mereka menunjukkan jumlah pelecehan wanita meningkat 9\% setiap tahun. Menurut catatan komisi pada tahun 2016, dari kasus pelecehan wanita, pelecehan seksual berada di peringkat kedua, dengan jumlah total kasus hingga 2.399 kasus (72\%), kasus pemerkosaan sekitar 601 kasus (18\%), pelecehan seksual mencapai 166 kasus (5\%) (Komnas Perempuan, 2019).

Kasus kekerasan seksual pada anak di dunia menurut data dari National Children"s Alliance (NCA) pada tahun 2013 terdapat 202,265 kasus. Tahun 2014 jumlah kasus kekerasan seksual pada anak meningkat menjadi 205,438. Namun terjadi penurunan kasus kekerasan seksual pada anak pada tahun 2015 dari bulan Januari sampai Juni menjadi 101,769. Sementara di Indonesia, Pusat data dan Informasi (Pustadin) Komisi Nasional Perlindungan Anak (Komnas PA) mencatat sepanjang tahun 2013 terdapat 1.620 kasus kekerasan pada anak dengan kasus kekerasan psikis sebanyak 313 kasus (19\%), kekerasan fisik sebanyak 490 kasus (30\%) dan kekerasan seksual menempati angka kejadian yang tertinggi yakni sebanyak 817 kasus (51\%) (Dewi et al., 2016).

Menurut data pelanggaran hak anak oleh Komisi Perlindungan Anak Indonesia (KPAI) ada 3.673 kasus kekerasan pada anak dalam kurun waktu tahun 2018 dan rata-rata terjadi 15 kasus setiap harinya. Hasil pemantauan KPAI dari 2013 sampai 2018, terjadi peningkatan yang signifikan. Tahun 2013 terjadi 4352 kasus kekerasan, tahun 2014 ada 5099 kasus, tahun 2015 ada 4338 kasus, tahun 2016 ada 4678 kasus, tahun 2017 ada 4632 dan tahun 2018 ada 3673, sedangkan untuk pelaku hampir sebagian besar pelaku adalah orang terdekat korban, misal-nya saudara, kakek bahkan ayah kandung korban dan rata-rata dari golongan masyarakat ekonomi bawah. Artinya, anak rentan menjadi korban 
kekerasan justru di lingkungan rumah. yang pelaku kekerasan mengenal anakanak tersebut dengan sangat dekat (Yulianti et al., 2019).

Sekitar 70 persen pelaku kekerasan terhadap anak adalah orangtua mereka sendiri. Dengan data fakta ini, KPAI berupaya melakukan programprogram edukasi kepada para orangtua agar dapat mencegah tindak kekerasan terhadap anak dengan melakukan hearing dan konsultasi pada anak dan orangtua. Dengan demikian, data tersebut semakin memperjelas gambaran muram tentang pemenuhan hak-hak anak Indonesia (Fajar et al., 2016).

Sebagian besar data CATAHU (Catatan Tahunan) yang dikompilasi Komnas Perempuan bersumber dari data kasus/perkara yang ditangani oleh PA. Dari total 406.178 kasus kasus kekerasan terhadap perempuan yang dikompilasi Komnas Perempuan pada tahun 2018, sebanyak 392.610 kasus atau $96 \%$ adalah data PA (Pengadilan Agama) dan 13.568 kasus atau 3\% adalah data yang berasal dari 209 lembaga mitra pengada layanan yang mengisi dan mengembalikan formulir pendataan Komnas Perempuan. Dari data berdasarkan kuesioner tersebut tampak kekerasan terhadap Perempuan di tahun 2018 dalam CATAHU 2019 mengalami peningkatan yaitu sebesar 406.178 kasus naik sekitar $14 \%$ dibandingkan dengan tahun sebelumnya CATAHU 2018 yaitu sebesar 348.446 (Komnas Perempuan, 2019).

Data Jumlah Korban Kekerasan Terhadap Perempuan dan Anak Yang Ditangani Oleh Pusat Pelayanan Terpadu Pemberdayaan Perempuan dan Anak
(P2TP2A). Berdasarkan Tempat Kejadian Kasus di Provinsi DKI Jakarta Tahun 2018 ada 217 korban. Kasus kekerasan seksual banyak dialami oleh anak-anak dan remaja, dikarenakan anakanak lebih cenderung mudah di pengaruhi dan di ancam oleh pelaku pelecehan seksual kekerasan seksual yang terjadi pada anak-anak merupakan suatu peristiwa krusial karena membawa dampak negatif pada kehidupan korban di masa dewasanya dan akan menimbulkan dampak seperti depresi, fobia, dan mimpi buruk, curiga terhadap orang lain dalam waktu yang cukup lama (Hartati, 2013).

Media komik efektif meningkatkan pengetahuan dan perilaku anak sekolah dasar dikarenakan media komik memiliki warna dan gambar yang menarik dan dapat mempermudah pemahaman. Salah satu kelompok anakanak yang rentan menjadi korban kekerasan seksual adalah anak-anak yang duduk di bangku sekolah dasar. Penelitian ini menyasar anak sekolah dasar khususnya dalam rentang umur 7-8 tahun, dimana pada rentang usia ini, anak sudah mulai memasuki masa pubertas, anak-anak sudah mulai mengalami perubahan fisik dan mulai tertarik pada lawan jenisnya. Pada masa ini anak juga mulai masuk ke dalam dunia yang baru, mulai banyak berhubungan dengan orang-orang di luar keluarganya dan berkenalan dengan suasana dan lingkungan baru dalam kehidupannya (Alodia et al., 2018).

Berdasarkan latar belakang di atas maka peneliti tertarik dan berkeinginan untuk melakukan penelitian dengan judul 
"Efektivitas Komik Edukasi Terhadap Upaya Pencegahan Kekerasan Pada Anak Sekolah Dasar Negeri Penggilingan 09 Pagi Jakarta Timur tahun 2019.

\section{METODOLOGI}

Penelitian ini menggunakan desain penelitian pra-eksperiment one group pre-test-post-test, hanya menggunakan satu kelompok saja yaitu kelompok eksperimen tanpa kelompok kontrol. Sebelum diberikan perlakuan, kelompok eksperimen terlebih dahulu diberikan pretest, kemudian diberikan perlakuan (treatment) dengan menggunakan komik edukasi dan setelah itu diberikan post-test. Populasi anak yang dipilih adalah anak sekolah dasar negeri 09 penggilingan kelas 1-A yang berdomisili di Jakarta Timur, dilakukan pada Juli 2019. Sampel yang diambil dari penelitian ini adalah 32 siswa. Instrumen yang digunakan adalah kuesioner dengan jenis pertanyaan tertutup dan dijawab responden sesuai dengan petunjuk kegiatan bertemakan upaya pencegahan kekerasan dengan menggunakan media komik. Anak akan diberikan komik mengenai upaya pencegahan kekerasan, dan dipelajari selama 1 minggu. Validitas digunakan uji statistik yakni teknik korelasi product moment. Reliabilitas dengan menggunakan uji Alpha cronbach's. Analisis data yang digunakan adalah menggunakan uji Paired sample ttest.

\section{S I}

Berbagai analisis hasil penelitian dijelaskan sebagai berikut:

\section{Analisis Univariat}

Tabel 1 Rata-rata perubahan perilaku siswa sebelum dan sesudah diberikan media komik di Sekolah Dasar Negeri Penggilingan 09 Pagi Jakarta Timur tahun 2019.

\begin{tabular}{cccc}
\hline Variabel & Mean & $\begin{array}{c}\text { Std. } \\
\text { Deviation }\end{array}$ & $\begin{array}{c}\text { Minimum- } \\
\text { Maximum }\end{array}$ \\
\hline Pretest & 62.72 & 6.417 & $50-73$ \\
Post test & 85.81 & 3.542 & $80-92$ \\
\hline
\end{tabular}

Berdasarkan tabel 1 diperoleh hasil penelitian bahwa rata-rata pengukuran perilaku menggunakan Skala Guttman sebelum intervensi yaitu mean 62.72 dengan standar deviasi 6.417 serta nilai minimum 50 dan nilai maximum 73 pada pengukuran perilaku setelah intervensi didapatkan mean 85.81 dengan standar deviasi 3.542 serta nilai minimum 80 dan nilai maximum 2.

\section{Uji Normalitas}

Tabel 2 Hasil Uji Normalitas Kolmogorov-Smirnov Pre-test dan Posttest Efektivitas Komik Edukasi Terhadap Upaya Pencegahan Kekerasan Pada Anak Sekolah Dasar Negeri Penggilingan 09 Pagi Jakarta Timur Tahun 2019.

\begin{tabular}{cccc}
\hline \multicolumn{4}{c}{ Kolmogorov-Smirnov } \\
\hline & Statistic & Df & Sig \\
Selisih & 0.126 & 32 & 0.200 \\
\hline
\end{tabular}

Tabel 2 menunjukan setelah dilakukan hasil uji normalitas menggunakan uji Kolmogorov-Smirnovselisih pretest dan posttest, didapatkan hasil nilai $p$ value 0.200 hal tersebut menunjukan bahwa data normal, karna dasar pengambilan keputusan bahwa berdistribusi normal bila hasil uji signifikan ( $p$ value $>0.05$ ). 


\section{Analisis Bivariat}

Tabel 3 Hasil Uji Paired Samples T-Test Efektivitas Komik Edukasi Terhadap Upaya Pencegahan Kekerasan Pada Anak Sekolah Dasar Negeri Penggilingan 09 Pagi Jakarta Timur tahun 2019.

\begin{tabular}{cccccc}
\hline \multirow{2}{*}{ Variabel } & \multicolumn{5}{c}{ Pre-test dan Post-test } \\
\cline { 2 - 6 } & $\mathrm{N}$ & Mean & $\begin{array}{c}\text { Std. } \\
\text { Deviation }\end{array}$ & SE & $\begin{array}{c}\mathrm{P} \\
\text { value }\end{array}$ \\
\hline Pretest & 32 & 62.72 & 6.417 & 1.134 & 0.000 \\
Post test & 32 & 85.81 & 3.542 & 0.626 & \\
\hline
\end{tabular}

Tabel 3 menunjukkan hasil Paired Samples T-Test yang menunjukkan nilai rata rata (mean) pre-test 62.72 dengan standar deviasi 6.417 dan nilai rata rata (mean) post test 85.81 dengan standar deviasi 3.542, nilai signifikansi $p$ value 0.000 sehingga $<0.05$. Karena $p$ value $0.000<0.05$ maka Ho ditolak. Hal tersebut menunjukkan bahwa data pretest dan posttest pada kelas 1-A terdapat pengaruh terhadap efektifitas media komik edukasi atau terdapat perbedaan antara hasil pretest dan posttest.

Hasil penelitian bahwa rata-rata pengukuran perilaku menggunakan Skala Guttman sebelum intervensi yaitu mean 62.72 dengan standar deviasi 6.417 serta nilai minimum 50 dan nilai maximum 73 pada pengukuran perilaku setelah intervensi didapatkan mean 85.81 dengan standar deviasi 3.542 serta nilai minimum 80 dan nilai maximum 92.

Kekerasan terhadap anak adalah semua bentuk atau tindakan perlakuan menyakitkan secara fisik ataupun emosional, penyalahgunaan seksual, trafiking, penelantaran, eksploitasi komersial termasuk eksploitasi seksual komersial anak yang mengakibatkan cidera atau kerugian nyata ataupun potensial terhadap kesehatan anak, kelangsungan hidup anak, tumbuh kembang anak atau martabat anak, yang dilakukan dalam konteks hubungan tanggung jawab, kepercayaan atau kekuasaan (Sulistyowati et al., 2018).

Menurut analisis peneliti, bahwa sebelum diberikan komik edukasi mengalami hasil perilaku siswa yang buruk, siswa belum mengetahui apa saja pencegahan kekerasan pada anak sehingga siswa diperlukan sebuah pembelajaran pemaparan informasi mengenai kekerasan melalui promosi kesehatan menggunakan alat bantu berupa komik atau pun media cetak yang lainya agar siswa dapat mengingat informasi yang disampaikan dan di harapkan siswa. Komik terbukti mampu membantu anak dalam proses belajar tentang pencegahan kekerasan pada anak, karena komik memberikan materi yang menarik dan memotivasi serta dilengkapi dengan dukungan visual. Itu artinya komik merupakan media yang cocok untuk isu kesehatan dengan sasaran anak. Penggunaan media dalam pendidikan kesehatan memiliki tujuan untuk menimbulkan perhatian terhadap suatu masalah dan mengingatkan informasi yang disampaikan supaya menimbulkan perubahan pengetahuan dan sikap pada siswa.

Berdasarkan hasil uji hipotesis, hasil Paired Samples T-Test yang menunjukkan nilai $p$ value 0.000 sehingga $<0.05$. Karena $p$ value $0.000<$ 0.05 maka Ho ditolak. Hal tersebut menunjukkan bahwa data pretest dan posttest pada kelas 1-A terdapat pengaruh terhadap efektifitas media komik edukasi atau terdapat perbedaan antara hasil pretest dan posttest.

Penggunaan media dalam pendidikan kesehatan memiliki tujuan untuk menimbulkan perhatian terhadap suatu masalah dan mengingatkan 
informasi yang disampaikan supaya menimbulkan perubahan pengetahuan dan sikap.

$\begin{array}{lrr}\text { Kekerasan } & \text { terhadap } & \text { anak } \\ \text { merupakan } & \text { cerminan } & \text { dari }\end{array}$ ketidakseimbangan pengaruh atau kuasa antara korban dan pelaku. Kekerasan terhadap anak mungkin terjadi hanya sekali tetapi mungkin melibatkan berbagai dampak yang secara tidak langsung dirasakan dalam jangka panjang, atau mungkin juga bisa terjadi berkali-kali dan semakin sering selama berbulan-bulan atau bertahun-tahun. Dalam segala bentuknya, kekerasan dan salah perlakuan berdampak pada keselamatan, kesehatan dan perkembangan anak (Fitria, 2017). Komik efektif meningkatkan pengetahuan anak sekolah dasar tentang kekerasan pada anak. Siswa dengan perilaku baik pada kelompok eksperimen mengalami peningkatan, dari $65.7 \%$, setelah edukasi menggunakan komik meningkat menjadi 91.4\%. Media komik efektif dan mampu meningkatkan pengetahuan dan sikap anak sekolah dasar. Terbukti dari hasil penelitiannya pengetahuan cukup $70 \%$ meningkat dari menjadi pengetahuan baik $87 \%$, sedangkan peningkatan sikap dari sikap negatif $67 \%$ menjadi sikap positif 77\% (Rahmanto \& Dwikurnaningsih, 2019).

Penelitian ini sejalan dengan Nuraini Hakim Hasil penelitian yang didapatkan yaitu terdapat peningkatan rerata self efficacy sebanyak 6,62 dan pvalue 0,001 . Hal tersebut menggambarkan adanya pengaruh yang signifikan antara pendidikan kesehatan melalui komik dengan self efficacy pada anak (Utami, 2018).

Menurut analisis peneliti, bahwa setelah diberikan komik edukasi mengalami perubahan perilaku menjadi baik yang berarti komik dalam proses pembelajaran bermanfaat membuat pengajaran lebih menarik perhatian siswa sehingga dapat menumbuhkan motivasi belajar siswa. Materi pembelajaran akan lebih jelas maknanya sehingga dapat lebih mudah dipahami oleh siswa dan memungkinkan siswa menguasai tujuan pembelajaran yang lebih baik. Pengajaran lebih bervariasi, tidak semata-mata komunikasi verbal melalui penuturan kata-kata oleh guru sehingga siswa tidak bosan (Saputra, 2016).

Pesan pembelajaran harus meningkatkan motivasi siswa. Pemilihan isi dan gaya penyampaian pesan mempunyai tujuan memberikan motivasi kepada siswa. Isi dan gaya penyampaian pesan juga harus merangsang siswa memproses apa yang dipelajari serta memberikan rangsangan belajar baru. Pesan pembelajaran yang baik akan mengaktifkan siswa dalam memberikan tanggapan, umpan balik pada siswa. dapat digunakan komik sebagai media belajar dalam upaya pencegahan kekerasan seksual pada anak usia dini (Yulianti et al., 2017).

\section{PENUTUP}

Terdapat hubungan yang bermakna efektivitas penggunaan komik edukasi dalam merubah perilaku siswa terhadap upaya pencegahan kekerasan pada Sekolah Dasar Negeri Penggilingan 09 Pagi Jakarta Timur tahun 2019.

\section{UCAPAN TERIMAKASIH}

Terimakasih kepada Sekolah Dasar Negeri Penggilingan 09 Pagi Jakarta Timur dan pihak yang terkait atas bantuan, bimbingan dalam penyelesaian penelitian ini. 


\section{DAFTAR PUSTAKA}

Adawiah, R. 2015. Upaya Pencegahan Kekerasan Terhadap Anak. Jurnal Keamanan Nasional.1(2): 279-296.

Al Haq, A.F., Rahardjo, S.T., Wibowo, H. 2017. Kekerasan Seksual Pada Anak di Indonesia, Prosiding Penelitian Dan Pengabdian Kepada Masyarakat. 2(1). Doi: 10.24198/ Jppm.V2i1.13233.

Alodia, D., Jesslyi, Anggreini, V. 2018. Kejahatan pedofilia sebagai perilaku menyimpang dan upaya penegakan hukumnya. Jurnal Muara Ilmu Sosial, Humaniora, dan Seni. 2(2):534-543.

Dewi, N.S., Arisanti, N., Rusmil, V.K., Sekarwana, N., Dhamayanti, M. 2016. Deteksi Dini Pengalaman Kekerasan Pada Anak di Tingkat Keluarga Di Kecamatan Jatinangor Early Detection of Child Abuse Experience At Family Level In Jatinangor Subdistrict. JSK. 2(3):123-129.

Fajar A., Sanjaya, R., Prasetya, H. 2016. Game Concept for Seual Child Abuse Anticipation. Sisforma. 3(1):6-12.

Fitria, M. 2017. Integrative Sex Education for Children. Jurnal Psikologi Integratif.5(1):76-93.

Hartati, M. 2013. Studi Tentang Upaya Penanganan Tindak Kekerasan Terhadap Perempuan Dan Anak (Studi Kasus Pada Pusat Pelayanan Terpadu Pemberdayaan Perempuan Dan Anak (P2tp2a) Provinsi Kalimantan Timur). eJurnal Administrasi Negara. 1(3):10941106.

Komnas Perempuan. 2019. korban bersuara, data bicara, sahkan RUU penghapusan kekerasan seksual sebagai wujud komiten negara. Catatan Tahunan tentang Kekerasan pada Perempuan, 16 Maret 2019:1-107.

Maknun, L. 2017. Kekerasan terhadap Anak yang dilakukan oleh Orang Tua (Child Abuse). Jurnal Madrasah Ibtidaiyah Muallimuna. 3(1):66-77.

Rahmanto, P., Dwikurnaningsih, Y. 2019. Pengembangan Media Komik Untuk Mencegah. G E N TA MULIA. X(1):105-121.

Ramadhanti. 2016. Komik edukasi pencegahan kejahatan seksual pada anak. e-Proceeding of Art \& Design. 3(3):696-707

Saputra, R.H. 2016. Peran pusat pelayanan terpadu perempuan dan anak (P2TPA) yogyakarta dalam menangani korban kekerasan seksual pada anak perspektif bimbingan dan konseling islam). Skripsi.UIN Sunan Kalijaga.

Sulistyowati, A., Matulessy, A., Praktito, 2018. Psikoedukasi seks: meningkatkan pengetahuan untuk mencegah-pelecehan seksual pada anak prasekolah. Jurnal Ilmiah Psikologi Terapan. 6(1):17-27.

Utami, PN. 2018. Pencegahan Kekerasan Terhadap Anak Dalam Perspektif Hak Atas Rasa Aman di Nusa Tenggara Barat. Jurnal HAM. 9(1):1-17.

Yulianti, P.D., Suyati, T., Rakhmawati, E., Chandra, A. 2019. The Development of Serial Assertive Comics about Reproduction Organs: Prevention Toward Early Child Sexual Abuse. GUIDENA: Jurnal Ilmu Pendidikan, Psikologi, Bimbingan dan Konseling. 9(1):1622. 